\title{
SOCIO-ECONOMIC AND INSTITUTIONAL PRECONDITIONS FOR THE FORMATION OF THE EDUCATIONAL SERVICES MARKET IN HIGHER EDUCATION OF UKRAINE
}

\author{
Anatolii Lomonosov', Oksana Lomonosova², Iryna Nadtochii ${ }^{3}$
}

\begin{abstract}
When considering the problems of the educational services market formation and functioning in higher education, most authors attribute the emergence of this market to fundamental political and economic changes in Ukraine in the early 1990s and its transition to a market economy. This approach is limited as the market for educational services has existed before. In the process of market expansion into public spheres in Ukraine in the last decade of the $20^{\text {th }}$ century, it got a generally completed form, although its formation has not yet ended and continues to transform. Over the past hundred and fifty years, the socio-economic system in Ukraine has changed three times: the second half of the 19th century - the transition from feudalism to capitalism, the beginning of the $20^{\text {th }}$ century - the transition from capitalism to socialism, the beginning of the $21^{\text {st }}$ century - the reverse transition from socialism to capitalism. The educational services market is one of the components of a market system of the country as a whole. The nature of socio-economic relations, of course, influenced the formation and functioning of the educational services market in higher education, which was under various factors affecting it in different socio-economic and institutional conditions. Therefore, this study considers three main historical stages of the formation of this market, each corresponding to a certain socio-economic system: - development of the educational services market in higher education of Ukraine in the late $19^{\text {th }}$-early $20^{\text {th }}$ centuries at the stage of formation and rise of capitalism; - functioning of the deformed educational services market in higher education of the Ukrainian SSR after the victory of the socialist revolution and in the Soviet Union era; - widescale introduction of market relations in higher education of modern Ukraine during the period of democratic transformations, changes in the socio-economic and political system, the abandonment of socialism and the return to the capitalist system. This approach, unlike most of those presented in modern Ukrainian economic literature, covers the entire historical period, in which there was a market for educational services in Ukraine's higher education. To ascertain the peculiarities and the characteristics of the market, at each stage the presence and development of its main elements should be determined. Those elements, as a rule, include goods, demand, supply, competition, and prices for goods or services. At all stages, the principal stimulator for the formation of the educational services market in higher education in Ukraine was the chronic underfunding of state higher education institutions. The dissatisfied demand of the population for higher education was also a significant factor in the formation and development of the educational services market. The market for educational services in higher education became developed after Ukraine had gained independence. Commercialization of educational services in higher education, the creation of private higher education institutions, the corresponding institutional transformations, and the legislative framework formation were typical for this stage. As a general scientific basis of the research, a dialectical method of analysis of socio-economic processes was applied. For the theoretical part of the study, historical-logical and abstract-logical methods were used, which allowed determining the key factors that caused the emergence of the educational services market in higher education of Ukraine, as well as to study the evolution of ideas about it. As the information base of the study, a set of legislative and normative acts of Ukraine and the Ministry of Education and Science of Ukraine, as well as some research works of domestic and foreign scientists concerning various aspects of the formation of the educational services market in higher education were used. For quantitative assessment of the market relations spread in higher education, statistical
\end{abstract}

\footnotetext{
Corresponding author:

${ }^{1}$ Admiral Makarov National University of Shipbuilding, Kherson Branch, Ukraine.

E-mail: lavloe@gmail.com

${ }^{2}$ Admiral Makarov National University of Shipbuilding, Kherson Branch, Ukraine.

E-mail: alvirginis@gmail.com

${ }^{3}$ Admiral Makarov National University of Shipbuilding, Kherson Branch, Ukraine.

E-mail: nira@ukr.net
} 
Vol. 5, No. 2, 2019

methods were used to process both complete and selective information. The basis of our research was the data of the State Statistics Service of Ukraine (from 1991 to 2017).

Key words: higher education, problems in higher education, educational services market development, educational services market in higher education in Ukraine, educational services market formation in higher education, commercialization of higher education.

JEL Classification: J40, L10, I25, N34, O15, P36

\section{Introduction}

Formation of a market for paid services in higher education should be considered one of the most significant events in higher education of the postSoviet Ukraine. This market is an integral part of the market economy and its emergence leads to the gradual transformation of social and economic relations in higher education. In the circumstances of the transitional economy and due to lack of information on the future need for specialists, it creates the basis for the transition from the strict centralized management to a flexible market regulation in higher education, combined with its state regulation. The educational services market in higher education with the elements of self-regulation serves as a connecting link between production and consumption of educational services provides communication between the higher education institutions (HEI), consumers of educational services and employers. This market significantly enhances the population's access to higher education, promotes increased operational efficiency and effectiveness of higher education institutions, and increases competition among them.

Currently, the development of the educational services market in Ukraine takes place simultaneously with the complex political and economic processes in conditions of economic, social, political, and demographic instability. In its modern shape, the educational services market has been formed over a relatively short period and socio-economic relations in the sphere of educational services cannot be considered well-developed. The regulatory support of the HEI performance in the market conditions needs significant improvement. It is necessary to note the inadequate elaboration of theoretical and methodological principles for the functioning of the educational services market, the fragmentary study of its problems, which does not correspond to the role of higher education in society, which is now on the path to its post-industrial phase.

The immaturity of economic relations on the educational services market has aggravated the socioeconomic problems in higher education, some of which were inherent in higher education of Ukraine before it has become an independent state. Some of these problems have become chronic. Among them one should note:

- reduction in state funding for higher education and the complexity of funding sources diversification for HEIs as a result of the difficult situation at the vast majority of enterprises; the unclaimed results of scientific research by production sphere and low solvency of the population;

- imbalance of demand and supply in the educational services market and inconsistency of the educational services market and the labour market;

- the negative demographic situation, which causes a reduction in demand for higher education;

- the outflow of the most talented youth from the regions to study at the universities of large cities of Ukraine and even in other countries from where they, as a rule, do not return after studying;

- poorly developed theoretical and methodological pricing principles for paid services in higher education; - the decline in the quality of education;

- low competitiveness of higher education system and insufficient volume of export of educational services;

- increase in educational services volume mainly due to the rise of training costs;

- the absence of reliable regional monitoring of the educational services market;

- insufficient state regulation of the educational services market, especially in the regions, etc.

To comprehend these problems, as well as their significance and better solutions to them, a further research on the educational services market in higher education of Ukraine seems to be necessary to determine the peculiarities of the educational services market formation and the study of its characteristic features that, in the conditions of transformation of the economic system, become of the utmost importance.

\section{Literature review}

There is much prior research in the Ukrainian contemporary economic literature on the problems of the educational services market in higher education of Ukraine. The general problems of the formation of this market in Ukraine are discussed in (Yeliseyeva at all, 2012; Karpyuk, 2009; Podzigun, 2014; Chekalovska, 2012). Great attention is paid to the statistical analysis of the development of this market in Ukraine, mainly the dynamics of its quantitative indicators (Karpyuk, 2009; Milevsky, Milevskaya, 2014; Malyukina, 2014; Chernysh, 2016). The educational services markets of the certain regions in Ukraine are investigated (Shender, 2013; Yurchuk, 2013), the ways to improve the state 
management of the development of these markets are determined by (Ambrazhey, 2011; Voyna, 2013). In some cases, despite the fact that the ascertaining of the essence and trends of the educational services market development was proclaimed as a research aim, the authors most carefully considered the educational services themselves (Yashchuk, 2013). At the same time, in the overwhelming majority of research papers, the authors avoid the analysis of the preconditions and the time of the emergence of the educational services market in Ukraine. Often its emergence is associated with the time when Ukraine proclaimed its independence (Yevmenkova, 2011; Yashchuk, 2013; Podzigun, 2014; Chekalovska, 2012; Karpyuk, 2009; Babiy, 2013; Malyukina, 2014; Chernysh, 2016; Petrenko, 2010, etc.). Sometimes, even in the research works, focused on the analysis of the educational services market emergence and development, this issue is not considered (Poyta, 2011).

In our opinion, to determine the availability of the educational services market in higher education of Ukraine in different periods of its existence and the characteristics of the main stages of its formation, a more thorough scientific justification is needed. Detection and correct interpretation of trends and prospects for the development of this market involves an analysis of the conditions of its formation, as well as the allocation of separate characteristic stages of its development and identification of their peculiarities.

The aim of this paper is to identify the complex of socio-economic and institutional preconditions and peculiarities of the educational services market formation in higher education of Ukraine.

\section{Results}

\subsection{The main approaches to determining the preconditions for the formation of the educational services market in higher education of Ukraine}

The formation of the educational services market in higher education of Ukraine is often associated with the fundamental changes in society that took place in the 1990s during the transition to a market economy. Various authors refer to commercial relations in higher education, paid education and the emergence of private HEIs as the main factors (or evidence) shaping this market.

The most widespread opinion regarding the emergence of the educational services market in higher education of Ukraine is that it appeared only due to the formation of a market economy in the early 1990s. According to K. M. Yevmenkova, "market transformations in post-socialist countries and in Ukraine, in particular, have led to the formation of the educational services market” (Yevmenkova, 2011). Similarly, T. A. Yashchuk believes that "market relations in the education of our country arose with the beginning of market reforms in the economy" (Yashchuk, 2013). A similar opinion is maintained by S. M. Podzigun (2014), G. S. Chekalovska (2012), and others. But, as mentioned below, part of market relations and some features of the educational services market in higher education of Ukraine existed in pre-revolutionary (before 1917), Soviet, and preperestroika periods. The transition to a market economy has only created opportunities for its development.

O. A. Karpyuk, R. P. Babiy, A. O. Malyukina and A. V. Chernysh, also tie up the educational services market with the 1990s and assert that its formation was caused by "the emergence of commercial relations in education, the formation of a network of private education institutions" (Karpyuk, 2009; Babiy, 2013; Malyukina, 2014; Chernysh, 2016). But the emergence of commercial relations and the formation of a network of private HEIs are not equivalent. Commercial relations are the root cause here, while the formation of a network of private HEIs is its consequence. Moreover, paid education in Ukraine existed almost all the time, since the end of the $19^{\text {th }}$ century.

L. M. Petrenko believes that the presence of the educational services market is evidenced by the fact that "educational services in the field of training the personnel for production, services, construction, etc. are provided by various organizations and institutions." Furthermore, in her opinion, "the emergence and steady growth of the share of paid services in the modern state sector of education indicate the existence of market relations in the field of vocational education and training" (Petrenko, 2010). Paid services and competition evidence market relations. But the fact that different organizations and institutions take part in the training of personnel is not a sign of the market. The market can function when only one manufacturer is present.

It should be emphasized that the complete denial of market relations in higher education in the times of the Soviet Union is erroneous. It is necessary to agree with the authors, who assert the earlier emergence of the educational services market. For example, A. M. Osmanov and A. M. Yesetova state that "the educational services market existed in the pre-perestroika period. But it was poorly developed, or rather, it was a state monopoly, and it significantly differed from its present state" (Osmanov, Yesetova, 2012). Indeed, the system of higher education was under pressure from the command-administrative system for many years; its activities, core indicators, and resource allocation were tightly planned and controlled.

Y. B. Rubin, noting the absence of a legal competitive market in the USSR, calls the Soviet order in the educational services market irrational and characterizes the market itself as a quasi-market (Rubin, 2011). At the same time, he points out the presence of the so-called "black market of near-educational services," which 
"permeated the activities of prestigious universities and faculties, despite periodic campaigns to combat bribes" (Rubin, 2011). Emphasizing the lack of competition in higher education, except for competition among the illegal operators of educational, as well as other services (coaches, corrupt officials, etc.), the author draws attention to the total nature of consumer competition for access to educational services and conditions of inequality for consumers depending on their nationality, party membership or belonging to "the chosen few."

It should be noted here that there was a certain competition for consumers among higher education institutions. This is especially true of the 1980s. Higher education institutions received an admission plan and had to fulfil it at any cost, so they conducted active career guidance work among young people, which in fact was an advertising campaign to attract university entrants.

The modern economic literature describes the emergence of a network of private HEIs (Karpyuk, 2009; Babiy, 2013; Malyukina, 2014 et al.) and the presence of tuition fees (Petrenko, 2010) as the main reasons for the formation of the educational services market and the evidence of its existence. But it should be emphasized that these phenomena existed before in Ukraine when it was part of the Russian Empire, as well as during the Soviet Union time. In the Russian Empire, tuition fees were introduced at state universities in 1817 for the first time, and then, when in the second half of the $19^{\text {th }}$ century there appeared non-government higher education institutions - they were introduced in them too (Derevyanko, 2013).

\subsection{Development of the educational services market in higher education of Ukraine at the end of the 19th and beginning of the 20th centuries}

At the turn of the 19th and 20th centuries, rapid industrial development and general economic growth in the Russian Empire, whose part Ukraine was then, led to a significant increase in the demand of employers for postgraduates, on the one hand, and the demand of the population for higher education on the other. It was the time when Kharkiv Institute of Technology, Kyiv Polytechnic Institute, Ekaterinoslav Mining College, Kyiv and Kharkiv Commercial Institutes were established. In Kharkiv, Agricultural Institute evacuated from Nova Alexandria began its work (Derevyanko, 2013). Institutes of the Russian Empire, including Ukraine, were unevenly filled up. For example, St. Petersburg and Kyiv Universities were extremely crowded and had a lot of students, while the provincial universities, especially their historical-philological faculties, had few or no students at all (Ivanov, 1991).

Ukrainian HEIs, as well as other educational institutions of the Russian Empire, were funded by the state but these funds were never enough to ensure their normal operation. At the beginning of the $20^{\text {th }}$ century, "the most important item of financial revenues after the state allocations was the tuition fees, which formed 'special funds' for higher education. Students covered the largest expenditures, which were not provided with budgetary allocations. The growth of the number of students led to a significant replenishment of these funds, which helped the educational institutions" (Ivanov, 1991). Special funds also included interest on universities' capital, income from specially created enterprises, income from the property sale, etc. (Belyakov, 2007), that is, income from entrepreneurship. In the Soviet Union, special funds became known as extra-budgetary ones.

In case of insufficient funding, HEIs usually solved their financial problems by raising tuition fees. The size of tuition fees was set by the institutions themselves. Thus, at St. Vladimir Kiev Imperial University in the 1880 s, in addition to tuition fees, students also paid fees to lecturers whose classes they attended (Mohylnyi, 2014).

As at that time, in the conditions of the development of capitalism, the state did not meet the growing needs for specialists, non-governmental (free) higher education institutions appeared. It was not subsidized by the state and was represented by two types of HEIs. The first type included the universities, which were created on an "ideological basis" at the initiative and expense of the bourgeois intellectuals as educational institutions. Funds from non-governmental organizations and philanthropists covered the universities costs and development, as well as material assistance to students. The second type included HEIs, which were organized on a commercial basis and had the aim of providing the founders with income in the form of interest on invested capital (Ivanov, 1991).

Non-governmental higher education institutions quickly adapted to changing conditions, organizing training new commercial and technical specialities, thereby increasing the supply of educational services. As a result of the growth of economic and social needs, at the end of 1916, there were 20 non-state higher education institutions operating in Ukraine (33.9\% of the total number of non-governmental HEIs in Russia as a whole) (Prokopenko, 2013).

Non-governmental HEIs, the first of which originated in the 1860s-1870s, were not supported by the state. Thus, at the turn of the $19^{\text {th }}$ and $20^{\text {th }}$ centuries, only in Ukraine the tsarist regime refused to establish Agricultural Institutes in Poltava, Simferopol, Kamianka, Polytechnic Institutes in Mykolaiv, Sevastopol, Simferopol, and Veterinary Institute in Kamianets-Podilskyi (Prokopenko, 2013). As a result of restrictions, non-state universities were established only in large cities. And only at the end of 1905 that it was officially allowed to open private "courses with a curriculum higher than average” (Ivanov, 1991). 
Not all private universities could successfully compete with government ones. That led to a "lack of people," and consequently, the financial non-viability of a certain part of them (Ivanov, 1991).

\subsection{The market elements in the Ukrainian SSR in the pre-perestroika period. Paid education}

The next year after the 1917 revolution paid education was abolished. The non-state universities ceased to exist. But the catastrophic shortage of funds for the universities' maintenance led to the reinstatement of tuition fees, which resulted in the fact that in 1922 in Ukraine almost $80 \%$ of students paid tuition fees. The students of medical and socio-economic HEIs paid the highest tuition fees (Kravchuk, 2011).

Different aspects of the tuition fees collection at educational institutions, including higher educational establishments, were regulated by a number of decrees of the AUCEC and the SPC of the RSFSR, which were adopted in 1923, 1924, and 1927, and by the decision of the SPC of the USSR in 1940. At the same time, various privileges for the military, the disabled, educators, etc. were established.

Higher education in Ukraine in the post-revolutionary period was characterized by the main elements of the educational services market. There were supply and demand for higher education. At the same time, demand was unregulated while supply was strictly regulated by the state in the Soviet Union. Almost all the time since the end of the $19^{\text {th }}$ century, students paid full or partial tuition fees. There wasn't a free price setting during the Soviet era. Pricing was the exclusive sphere of the state, not the HEIs. Ultimately, tuition fees at the universities of the Soviet Union were cancelled only in 1956.

As it was mentioned above, there was competition among the HEIs for consumers. Admission to universities was carried out on a competitive basis. That is, there was simultaneous competition between providers and consumers of educational services.

Students did not cover the full cost of their studies. The maximum tuition fees were limited by the state, though students who had good results could receive a scholarship. Due to the limited size, the fees only partially covered the costs of the university operation, supplementing government allocations. It is interesting to mention that the specialists' training for business entities could be carried out on the basis of agreements between the HEIs and these entities when the latter paid for specialists' training, though both the HEIs and business entities were state-owned. (Derevyanko, 2013). In the Soviet Union, apart from tuition fees, universities could have other extra-budgetary funds. Extra-budgetary funds included rent of university buildings and hostels (these funds were used for their maintenance, equipment, and repair), revenues from transport (intended for its maintenance, repair, and replenishment), revenues from production activities of auxiliary enterprises and farms (spent on their organization, current maintenance, and expansion), etc. Planning and control over extra-budgetary expenditures were the same as over budget ones. The largest income source was self-supporting research work on orders of enterprises and industry research organizations.

Thus, one should recognize that there was the educational services market in the Ukrainian SSR, though it was limited, undeveloped, deformed, and strictly regulated by the state.

\subsection{The educational services market in higher education of modern Ukraine}

\subsubsection{Market relations in higher education}

The idea of the need for a broad introduction of market relations in higher education, according to authors of the monograph edited by O. Tikhonov, was disseminated in the 90s of the last century (Tikhonov, 1998). On this occasion, in 1990, Guy Neave, a world-famous specialist in higher education policy in Europe and in European integration, who then was Director of Research for the International Association of Universities (IAU) in Paris, describing the tendencies in higher education of Western Europe in 1988-1990, points out that "market should be considered the main element underlying the European policy in higher education" (Neave, 1990). This is also true for North American universities (Buchbinder, Newson, 1991). A well-known British economist, a former adviser to M. Thatcher, Douglas Hague claimed in 1991, that under present conditions, "liberal universities" should be replaced by universities which "operate as a business in the field of science" (Hague, 1991).

The concept of entrepreneurial university appeared in the mid-1990s. According to Burton R. Clark, such a university is focused on innovation, knowledge commercialization, diversifying of funding base, close connection with the environment (Clark, 1998). Today, the signs of the entrepreneurial university include entrepreneurship in research, educational, and other activities, obtaining a financial result from these activities, competitiveness in the markets of research, vocational educational services, labour, finance and commodities (Bunyak, 2016).

In the Soviet Union, including Ukraine, the transformation of the economic system and its transition to market relations took place in the second half of the 1980s and the beginning of the 1990s. These changes spread to the entire society. Higher education was not spared by them either. Thus, the expansion of the market into all spheres of public life in Ukraine coincided with the introduction of market relations in higher education in Western Europe and North America.

The main factors in the development of market relations in education, according to the authors (Tikhonov, 1998) are the following: 
- the acquisition the status of fixed capital by knowledge in society and funding sources diversification in education;

- changing the role of the state in education;

- spread of neo-conservative ideology;

- development of new information technologies.

\subsubsection{Financial problems of higher education institutions as the factor that accelerated the formation of the educational services market at the end of the $20^{\text {th }}$ century}

A number of socio-economic preconditions necessary for the formation of the educational services market were present in the pre-perestroika period in Ukraine. They are: division of labour and specialization; the relative economic isolation of universities, which acted as business entities and offered training in their specialities (as well as in certain new ones); the presence of steady demand for higher education; freedom and independence for consumers to choose universities and specialities (this demand was unregulated, although the state regulated the number of places in each speciality); certain competition among consumers and among the majority of universities.

But there was no academic, financial, and organizational autonomy, pedagogical freedom of educators, freedom of research, learning, etc. Economic, financial, organizational decisions, decisions on educational and research programs, the forms of studies, and other matters were necessarily consistent with the higher institutional level organization. The state regulated the size of the tuition fees. All this made the education services market undeveloped, inferior but, albeit in a deformed state, it still existed.

As already noted, during the Soviet era, in addition to budget allocations, universities could have extra-budgetary funds, which they received mainly as a result of selfsupporting research work on orders of enterprises and industry research organizations. Thus, the total income of the HEI consisted of two parts: budget allocations and extra-budgetary funds. In the first half of the 1960s, the share of the latter was more than $20 \%$. In the future, the share of extra-budgetary funds in the total proceeds steadily increased, reaching almost $50 \%$ in the late 1980 s (Table 1).

In the second half of the 1980s, in the era of perestroika, together with economic reform and accelerating socioeconomicdevelopment of the country, therewas atransition of enterprises to self-financing. Similarly, an attempt was made to transfer higher education to the new conditions of management because the overwhelming part of them was experiencing difficulties. To stimulate the growth of selfsupporting research work and attract additional revenues to finance their activities, since 1987, they were allowed to form an accumulation fund in the amount of $20 \%$ of selfsupporting funds. They could also manufacture products, provide organizations and people with paid services in the field of culture, passenger transportation, health resort services, physical culture and sports, housing, etc. That is, they got the opportunity to provide a large range of paid services. Moreover, they even had pre-planned tasks for paid services development. But since these plans were not carried out (Butenko, 1990), self-supporting research was the main source of extra-budgetary funds.

As it was mentioned above, in the Soviet Union enterprises, institutions, collective farms, etc. could fund HEI's activities to some extent. For example, the Kherson branch of the Mykolaiv Shipbuilding Institute (now National University of Shipbuilding), founded in 1967 , for more than thirty years was financed from the budget, and funds allocated by the Kherson Shipyard. At the same time, in the total amount of HEIs' financing, the share of enterprises in comparison with the volumes of state budget revenues, if any, was negligible. Most often those enterprises gave outdated equipment, devices and materials, etc. for free.

Thus, HEIs got funding from several sources. But the main source was funding from the state budget, and they used it for direct student training.

The economic and social processes that took place in the Soviet economy in the second half of the 1980s did not allow universities to increase the volume of work, services, etc. for enterprises and population, as the financial situation of universities and the State Committee on Science and Education authorities required. Moreover, there appeared some new problems. Many enterprises were on the verge of bankruptcy as a result of the rupture of economic ties among them, a drop in effective demand, inflation, etc.

The situation became more complicated because the enterprises of the military-industrial complex always had priority development. The conversion of the military-industrial complex broke traditional ties among businesses and industries. Instead of high-tech production, enterprises were forced to produce simpler and cheaper goods, but which in conditions of inflation were in demand. The difficult financial situation of enterprises and their refusal to produce and develop

Table 1

The ratio between funding sources for higher education in the Ukrainian SSR in 1961-1988

\begin{tabular}{|l|c|c|c|c|c|c|}
\hline \multirow{2}{*}{ Sources of funding } & \multicolumn{7}{|c|}{ Source share on average over the period } \\
\cline { 2 - 7 } & $1961-1965$ & $1966-1970$ & $1971-1975$ & $1976-1980$ & $1981-1985$ & $1986-1988$ \\
\hline Budget allocations & 77,5 & 74,4 & 66,4 & 61,8 & 56,2 & 51,5 \\
\hline Extra-budgetary funds & 22,5 & 25,6 & 33,6 & 38,2 & 43,8 & 48,6 \\
\hline
\end{tabular}

Source: compiled by the authors according to (Chugaev, 1990) 
new complex, high-tech products led to the curtailment of research, in which HEIs were involved.

The crisis situation at the enterprises led not only to the mass termination of their interaction with universities in the field of research but also to a significant reduction in the need for young professionals. At that time, production did not require a large number of new professionals because of its significant reduction, a decrease in its technical level, and lack of financial resources even to stay viable.

Thus, there was a reduction of the budget financing and a simultaneous decrease, or the complete disappearance of opportunities for higher education institutions to receive extra-budgetary funds.

It should be emphasized that the higher education of the Soviet Union was in a difficult situation not only because of the financial problems and enterprises' degradation in the 1980s. Insufficient funding of higher education for many years influenced the ways and dynamics of its development, its content, and quality.

All this, together with other factors that negatively affected higher education led to the fact that in the late 1980 s the condition of higher education in the USSR was recognized as a crisis one. For example, in (Gausner et all., 1992), the authors directly point out the crisis of the system for staff training and retraining. They give three main reasons for that. The first one is a sharp decrease in the financing of education from the state budget. The second one is the reduction of funds allocated by enterprises for training and retraining of staff. The third reason is the lack of demand for professional knowledge of an increasing number of professionals as a result of the falling demand for high-tech products.

New socio-economic problems, generated by the transition from the command-and-control economy to a market one, aggravated the old unresolved financial problems in Ukraine's education in the 1990s. Denationalization, democratization, and liberalization led to the emergence of complex and controversial processes, as well as significant economic, political, and social changes in society.

In the early 1990s, there was a sharp increase in energy prices (gas prices increased 100 times, oil prices 300 times in 1992), in production cost prices, and a significant drop in industrial and agricultural production. Even a simple reproduction of fixed assets became impossible. There was inflation and then hyperinflation in 1992-1995. At the same time, the economic potential of the country decreased almost twice, as well as its scientific and technical potential, the structure of social production deteriorated, unemployment and social insecurity increased, there was a significant differentiation in people's incomes (Chumachenko, 2000).

The deepening of the crisis was facilitated by such factors as: the deformed structure of the national economy of Ukraine, which once was the part of the Soviet one, focused primarily on the military-industrial complex needs; backward agriculture; poor control of all transformational processes at the macro level; the presence of a significant number of environmentally hazardous and power-consuming enterprises. It is natural that under such conditions, there was a further reduction of the state budget of Ukraine, and funding of education significantly deteriorated.

Starting from 1994 and almost to the beginning of the 2000s, budget funds were allocated, as a rule, only to salaries and scholarships, but they were not enough for these purposes, they were received and paid with considerable delay. The state wage arrears in HEIs were eliminated only in the late 1990s. Many of the educational institutions were on the verge of survival.

The funding cuts and difficult situation in the country forced HEIs to adhere to austerity measures, even to the detriment of the quality of training. Therefore, HEIs, along with the introduction of a strict economy, constantly sought out additional sources of funding.

The only way out of the situation could be to provide higher education institutions with the opportunity to get additional funds. The Law of Ukraine "On Education", adopted by the Verkhovna Rada of the Ukrainian SSR in 1991, in addition to funding public education institutions at the expense of the corresponding budgets, funds of the sectors of the national economy, state enterprises and organizations, provided additional sources of funding. Universities got permission to receive funds for training and retraining according to the concluded contracts; to provide additional educational services; to perform scientific research and other types of work. Unlike the Soviet period, universities now could independently set the size of tuition fees, decide on the size of contract prices for performing various work.

The financial capabilities of the majority of enterprises and organizations led almost to a complete reduction of research work, and other activities (manufacturing and repairing of machines, appliances, inventory, etc., providing transport services, leasing premises and equipment, etc.) allowed getting only insignificant additional revenues. In this regard, the main source of income for public universities, in addition to budget financing, was the tuition fees, due to which they received $70-95 \%$ of the proceeds to the special fund in this period.

Getting additional funds from the paid students' training is the most simple for HEIs since it allows them to concentrate primarily on their core activities (educational and research ones).

The organization of paid training provides for the availability of appropriate demand from enterprises and the public. As a result of the unsatisfied effective demand for higher education in the first years of Ukraine's independence, there was a rapid increase in the number of those who paid tuition fees at the HEIs. In 2006, the number of students enrolled in state and municipal higher education institutions for studying for the funds of individuals and legal entities reached its maximum 
value -246.8 thousand people (Figure 1). It also was facilitated by an increase in the number of secondary school leavers. The gradual decrease in the number of students who paid tuition fees began after 2005. Their minimum value after the maximum of 2006 was in 2015 when 104.7 thousand people were enrolled.

One should take in account that in Ukraine at the beginning of the 2016-2017 academic year, there were only 13 municipal HEIs, making up $4.5 \%$ of the total number of HEIs (Main indicators, 2017). 1.8\% of students study there. That is, Figure 1 practically illustrates the dynamics of students' admission to state higher education institutions.

The rapid increase in the admission of students to study for the funds of individuals and legal entities led to the fact that their number in 1999 reached, and during 2000-2007, as well as in 2010, exceeded the number of students who got the state-supported places. In 2016, the proportion of students who entered the state and municipal higher education institutions for studying at the state budget funds amounted to 54\% of the total number of students enrolled that year.

\subsubsection{The emergence and development of a non-state sector of higher education in independent Ukraine}

The formation of the educational services market was also facilitated by the emergence and development of the non-state education sector. There is a widespread belief that the first non-state higher education institutions appeared after the Law of the Ukrainian
SSR "On Education" was adopted in 1991, which legally established the equal rights of all education institutions, including higher education, regardless of the form of ownership (Zerkal, Siryi, 2016).

But the emergence of non-state education is related to the restructuring, which began in the second half of the 1980s, the democratization of society, the formation of market relations in the economy, the recognition of private property. The significant role here played the desire of creative personalities to free themselves from strict regulations, as well as their disappointment with their financial situation, which did not match their qualifications, erudition, creativity, pedagogical and organizational skills.

The first non-state universities in Ukraine appeared in the mainstream of the slogan "what is not forbidden is allowed" in the late 1980s, which corresponds to the liberal-democratic principle: "everything that is not forbidden is allowed." These non-state higher education institutions were of various organizational and legal forms. It was especially true for universities that were created prior to the adoption of legislative norms that regulated the HEIs establishment and activities in the new socio-economic conditions.

For example, the well-known Interregional Academy of Personnel Management was founded in Kyiv in 1989 as a cooperative "Kyiv Research and Implementation Centre "Kadry" with the right to conduct educational, methodological and publishing activities. Cooperatives at that time were the most widespread organizational and legal form of entrepreneurship, which was in line with the rapid development of the cooperative movement.

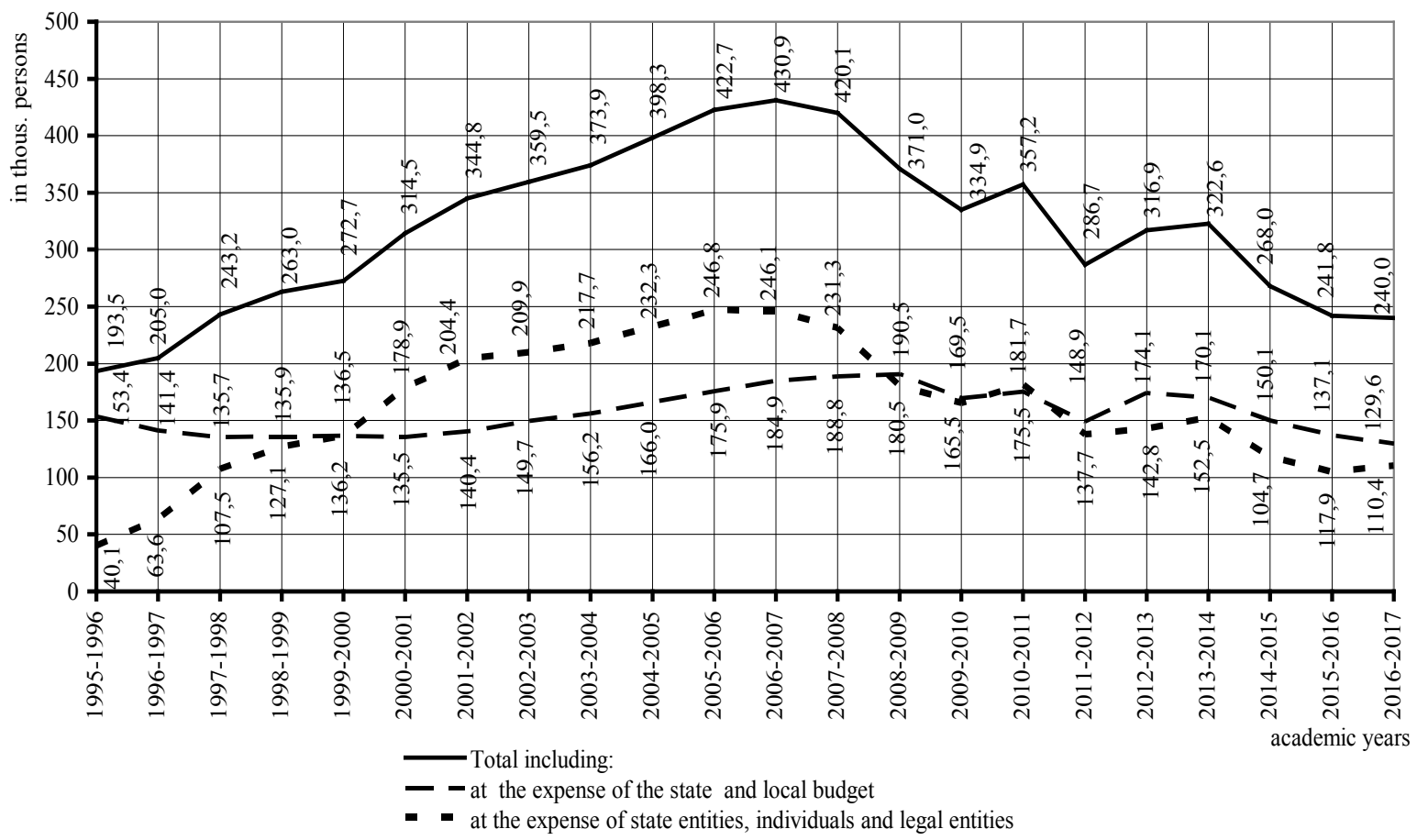

Figure 1. Students' enrolment at state and municipal higher education institutions by the sources of funding 
The private HEI "International Management Institute" was created as a joint venture organized by the Swiss International Management Institute and the Institute of Economics of the Academy of Sciences of the UkrSSR in 1989. Kharkiv Institute of Social Progress was founded in 1990, before the formation of a modern legislative framework for education.

In 1991, the Laws "On Enterprise in the Ukrainian SSR", "On Entrepreneurship in the Ukrainian SSR" and "On Education" formed new institutional preconditions for the further development of higher education in Ukraine. In particular, they officially eliminated the state monopoly on providing paid services in education, recognized the possibility of establishing HEIs of the non-state form of ownership, and equated them to state universities.

The Law of the Ukrainian SSR "On Education" stipulated that "the activities related to the provision of services for education and training of specialists of different levels of qualification" only begin when a license is available. But "at the same time, the licensing and accreditation system was merely declarative" (Horpynych, Salov, 2012). Since 1996, the procedure has got its modern form, and "normalization, systematic character, and orderliness appeared in licensing and accreditation work" (Horpynych, Salov, 2012).

Newly established non-state HEIs actively filled vacant niches in the higher education services market. It was, first of all, training of students in economic, managerial, legal, and other specialities that were in demand by the population, and which state universities were not able to satisfy at that time. Besides, training in these specialities did not require laboratory facilities and equipment, which made it possible to start the educational process rather quickly.

Starting in 1993, the process of active emergence of new non-state higher education institutions began. It continued until 2007 when the number of HEIs reached its maximum ( 115 HEIs). After that, their number declined to 78 in 2016 (Figure 2). It is noteworthy that the dynamics of changes in the number of state and non-state HEIs from 1996 to 2016 was identical. Therefore, the share of non-state universities in this period fluctuated within rather narrow limits - from $27.2 \%$ to $32.4 \%$.

The main reasons for reducing the number of universities, including non-state ones, is a significant decrease in secondary school graduates, as well as increased control over the quality of training from the state. At the same time, entrants in Ukraine continue to prefer state higher education institutions. Thus, between 1995 and 2016, the number of students enrolled at state higher education institutions was much higher each year than the number of those who entered private HEIs (Figure 3).

Since 1995, the number of students enrolled at universities of all forms of ownership has been steadily increasing and in 2006 reached its maximum value ( 507.7 thousand people). In the same year, the number of students enrolled at the state and municipal higher education institutions was the largest one (430.9 thousand people). The maximum number of those enrolled at non-state higher education institutions was in 2005 ( 80.3 thousand).

After that, the number of entrants began to decrease, and in 2017 this figure reached its minimum. 264.4 thousand people were enrolled at all universities

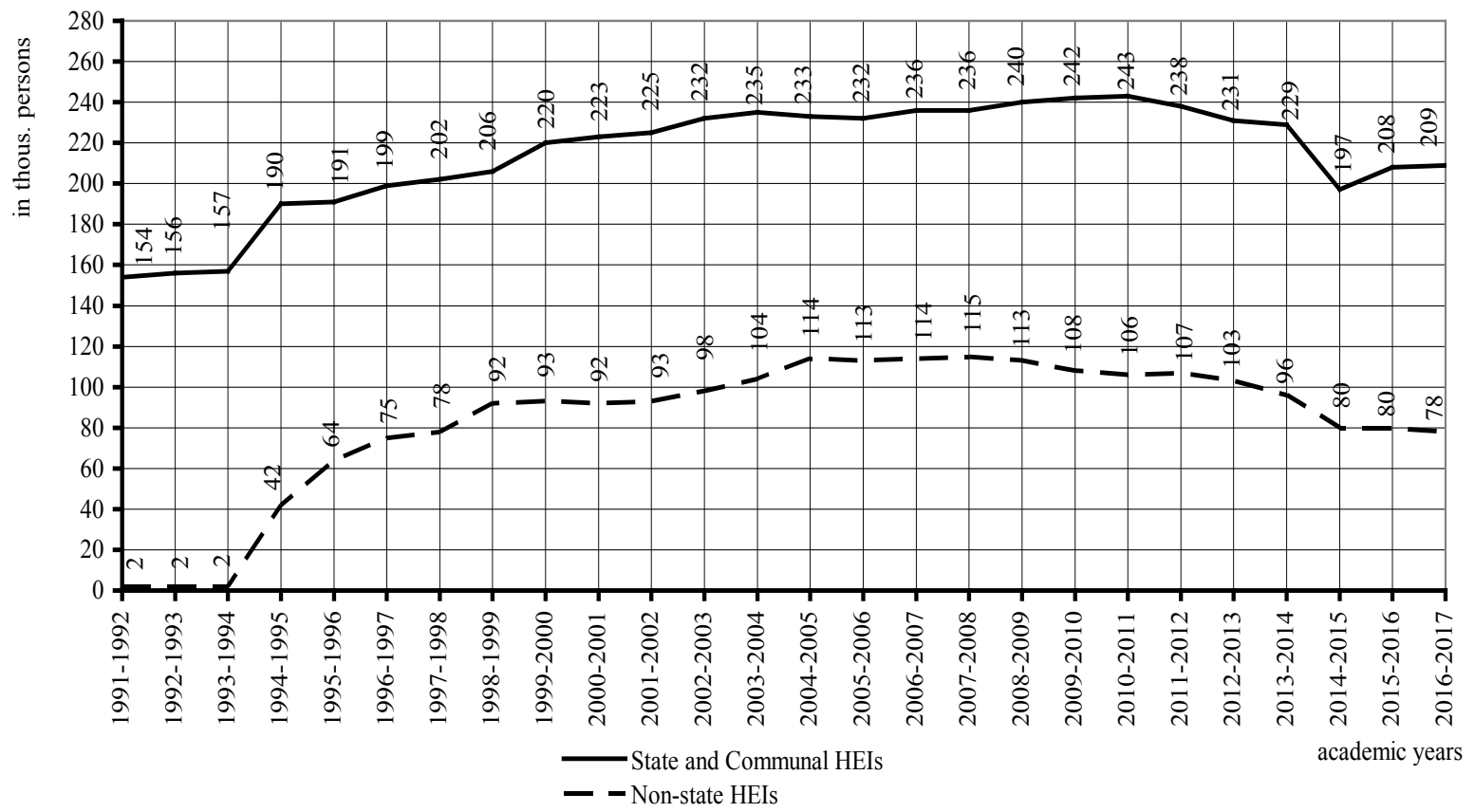

Figure 2. Dynamics of the number of state, communal and non-state higher education institutions in Ukraine in $1991-2016$ 


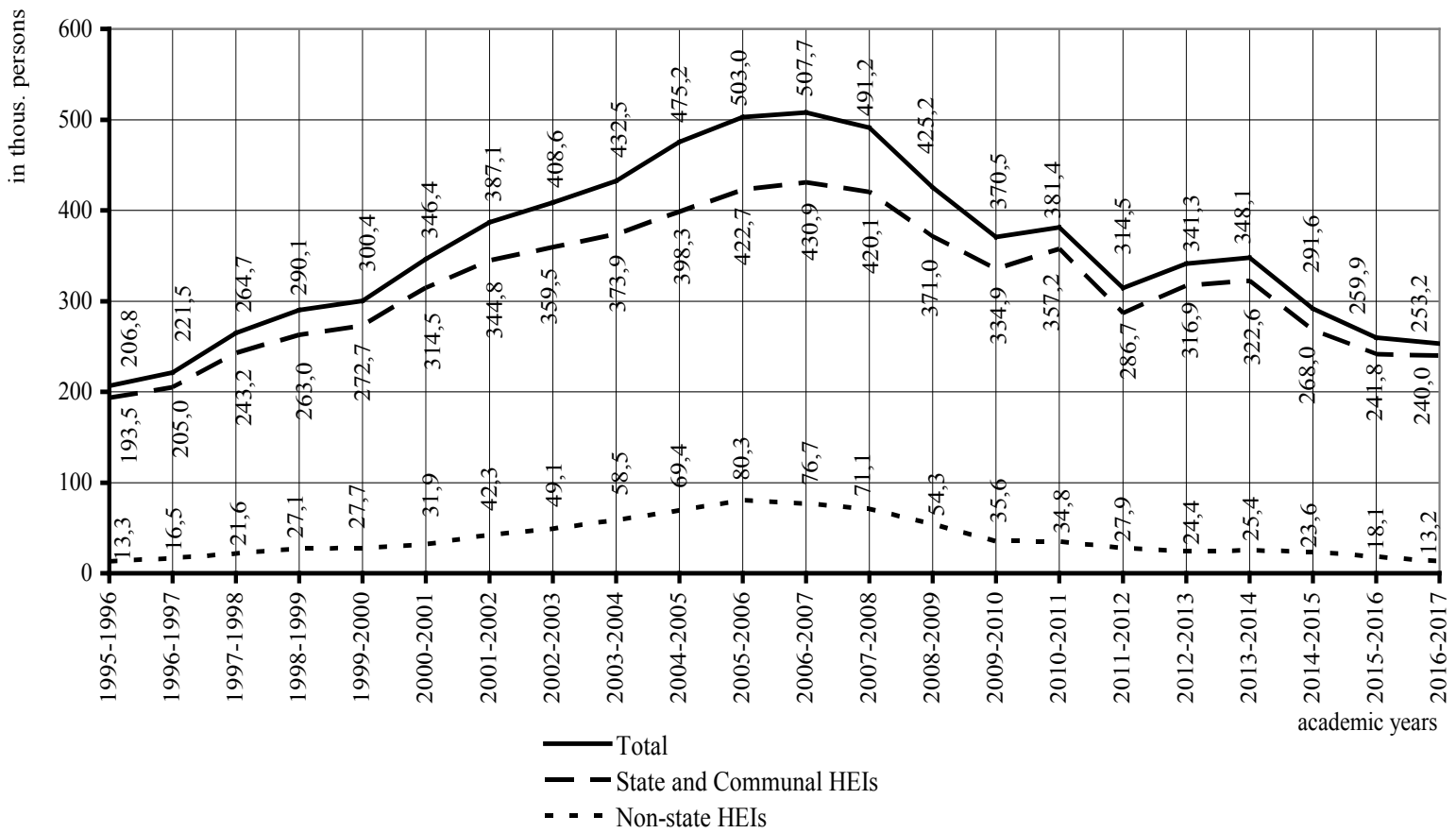

Figure 3. Enrolment at HEIs of Ukraine by forms of ownership

of Ukraine, that is, twice less than in 2006. At that, 248.2 thousand people enrolled at state and municipal HEIs, which is $57.6 \%$ of the same indicator in 2006. Only 16,200 persons entered non-state HEIs in 2017, which practically corresponded to the level of 1995 (13,300 people). The proportion of students enrolled in non-state HEIs during the whole period under consideration is insignificant. It ranged from
$16.0 \%$ (in 2005) to $6.5 \%$ (in 2017). Moreover, during the fourteen years (from 1995 to 2000 and from 2009 to 2016 ) the value of this indicator did not exceed $10 \%$.

Entrants enrolled at HEIs for paid training also prefer state universities. It is evidenced by the admission results of those enrolled for paid training, in state and communal as well as non-state universities in Ukraine in 1995-2016 (Figure 4). The proportion of the number of

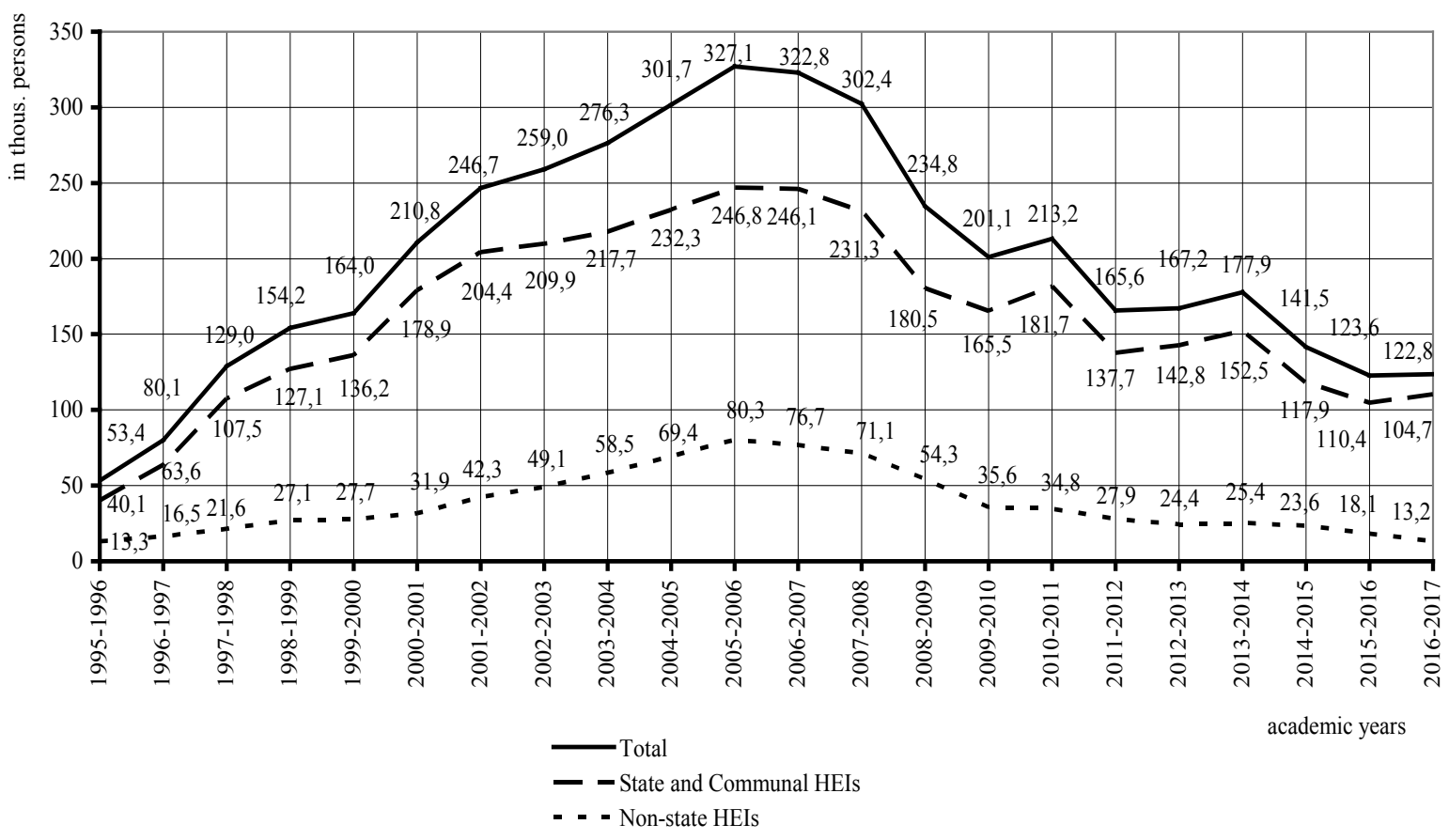

Figure 4. Enrolment at HEIs of Ukraine by forms of ownership, at the expense of state entities, individuals, and legal entities (paid education) 
students admitted at non-state HEIs in the total number of students enrolled for paid training at state and nonstate HEIs in the period under consideration ranged from $24.9 \%$ (in 1995) to $14.3 \%$ (in 2013). This figure reached its minimum value in 2016 when it was $10.7 \%$.

For comparison, we should note that in the world, the proportion of students whose training was financed by private sources during 2011-2015 amounted to about $27 \%$. Accordingly, public funding provided $73 \%$ of students (BusinessStat).

The given information testifies to the minor role of non-state HEIs, which they play in the modern educational services market of Ukraine. Although in the early 1990s it was thought that they would create significant competition with state universities.

Applicants attempting to enter state HEI for public procurement, in the event of failure, go to the same university for paid training. Sometimes consumers have a certain degree of distrust to the quality educational services at non-state universities. There are grounds for this since a significant part of their scientific and pedagogical staff is full-time teachers of state universities and at non-state ones, they work on a part-time basis, which often affects their attitude to their duties. A characteristic feature of the third stage of the educational services market development in higher education is the competition among HEIs for students. At this stage, unlike the first two (the end of the $19^{\text {th }}$ - the beginning of the $20^{\text {th }}$ centuries and the Soviet period), it has become significant. Institutions of higher education tried to increase the admissions of students for paid training. It allowed state institutions to receive funds to compensate for state underfunding and to ensure development, while for private ones it was the primary source of funding. A particular intensification of competition took place, starting in mid-2006 when there was a decline in the number of applicants due to the decrease of secondary school graduates. In these circumstances, it is very important for state HEIs to prevent reduction of the number of students, as it influences the number of academic staff positions. (Lomonosov, Lomonosova, 2007).

\section{Conclusions}

There are three stages of the formation and distribution of the higher education services market in Ukraine. Each of them has led to obvious qualitative changes in the state of the educational services market and corresponds to the socio-economic system that existed in Ukraine during a certain period of history.

The first stage - the end of the $19^{\text {th }}$ century - the beginning of the $20^{\text {th }}$ centurycoincides with the emergence of capitalism. The main factors of the emergence of market relations in higher education were the rapid growth of employers' demand for professionals with a university degree, simultaneously increased demand of the population for it, as well as insufficient funding of state universities, which led to the distribution of paid training. There appeared two types of non-state universities. The first ones were founded on the "ideological basis" for educational purpose; the others, based on commercial principles, were intended to generate profit.

One of the features of the second stage in the Ukrainian SSR period was fee-paying education, which took place in state universities (non-state ones were abolished). The size of tuition fees was regulated by the state, though they did not cover all expenses of the university. There were various benefits for some categories of students. Tuition fee system at Soviet universities existed until 1956. There was some competition present among the HEIs for consumers, although that was the situation that strictly regulated supply. Demand for higher education was unregulated and dissatisfied.

In addition to budgetary allocations as the primary funding source, universities had some extra-budgetary funds. The most money came from enterprises and industry research organizations as the fees for research and development.

All this testified to the presence of a market in the Ukrainian SSR, although it was underdeveloped, deformed, imperfect, and controlled by the state.

The third stage is related to the liberalization of the economy and market transformations in Ukraine. It began in the second half of the 1980s when Ukraine was part of the USSR and practically coincided with the dissemination of entrepreneurial university ideas in the world.

The radical changes in society that took place in the 1990s spurred the development of the educational services market in higher education. After Ukraine gained independence in 1991, this stage of the educational services market formation in higher education is the most important, essential, and completed. It is characterized by the commercialization of educational services in higher education. In contrast to the first stage (the end of the $19^{\text {th }}$ and the beginning of the $20^{\text {th }}$ centuries), the creation of private HEIs was not limited and had a clear legal framework. In the period of the USSR, there were no private universities at all.

The activating means for the development of the educational services market in higher education at all stages of its formation and distribution was insufficient funding. Chronic underfunding of state HEIs made them actively seek out additional sources of funding, and even before Ukraine became independent, formed powerful motives at universities to provide paid services to enterprises, institutions, and the population.

Thus, the higher education of Ukraine, since the end of the $19^{\text {th }}$ century, has been characterized by the main elements of the educational services market: supply and demand for higher education, competition among higher education institutions for consumers and competition among consumers for places in HEIs, tuition fees (full or partial). 


\section{References:}

Ambrazhey, O. A. (2011). State regulation of the educational services market of Ukraine. Bulletin of the Chernivtsi Trade and Economic Institute. Economic sciences, 2(1), 402-405.

Babiy, R. P. (2013). Theoretical Foundations of the Educational Services Market Development in the Period of Transformation. Scientific Bulletin of the NLTU of Ukraine, 23.15, 372-376.

Belyakov, S. A. (2007). New lectures on the economics of education. Moscow: MAX Press.

Buchbinder, H., Newson, J. (1991). Social knowledge and market knowledge: universities in the information age. Gannett Center Journal, 5(2-3), 17-29.

Bunyak, N. M. (2016). Entrepreneurial University: the essence and peculiarities of formation. Juvenis scientia, 2, 144-147.

BusinessStat. Analysis of the World Market for Higher Education in 2011-2015, forecast for 2016-2020. Retrieved October 102018 from: http://businesstat.ru

Butenko, N. Yu. (1990). Reproduction of specialists with a degree. Kyiv: Vyshcha shkola.

Chekalovska, G. S. (2012). Efficiency of the functioning of the educational services market in Ukraine: problems and perspectives. Economy and management of the national economy, 3, 59-64.

Chernysh, O.V. (2016). Analysis of current trends in the development of the educational services market in Ukraine. Bulletin of the Kyiv National University of Technology and Design. Special issue: The effectiveness of the organizational and economic mechanism of innovative development of higher education in Ukraine, 114-121.

Chugaev, A. A. (1990). Higher school and production (interaction: planning and economic management methods). Kyiv: Vyshcha shkola.

Chumachenko, M. (2000). Stages of economic growth, unfortunately, not yet stable. Economist, 12, $26-27$.

Clark, B. R. (1998). Creating Entrepreneurial universities: organizational pathways of transformation. Issues in Higher Education. Oxford: Pergamon Press.

Derevyanko, B. V. (2013). Services in education: legal regulation: monograph. Donetsk: Publishing House "Kalmius".

Gausner, N., Ivanov, N., Mikhina, M. (1992). The Strategy of Human Resource Development in the Conditions of the Transition to the Market. World Economy and International Relations, 9, 30-45.

Horpynych, O. V., Salov, V. O. (2012, March). Evolution of specialties licensing and accreditation procedures. Paper presented at the Conference "Personnel training quality management through improvement of licensing, accreditation and rating procedures". Dnipropetrovsk, 37-42.

Ivanov, A. E. (1991). High education in Russia at the end of the $19^{\text {th }}-$ beginning of the $20^{\text {th }}$ century. Moscow.

Karpyuk, O. A. (2009). Analysis and assessment of the level of development of the educational services market in Ukraine .Journal of ZHDTU. Economic sciences, 3(49), 74-78.

Kravchuk, H. A. (2011). Student Organizations in the Ukrainian SSR in the 1920's: abstract of the thesis for a Candidate Degree in History: 07.00.01. History of Ukraine. Kharkiv.

Lomonosov, A. V., Lomonosova, O. E. (2007). Calculations of the academic staff number in higher education institutions of III-IV accreditation levels. Economist, 1, 48.

Malyukina, A. O. (2014). Analysis of the educational services market in Ukraine. Global and national problems of the economy, 2, 617-620. Retrieved from: http://global-national.in.ua/archive/2-2014/125.pdf

Milevsky, S. V., Milevskaya, S. V. (2014). Analysis of the Educational Services Market in Ukraine. Scientific Bulletin of Kherson State University, 8(3), 34-39.

Mohylnyi, L. (2014). The St. Volodymyr Kiev Imperial University in 1884-1914. Journal of Ukrainian History, 30. Neave, G. (1990). On preparing for markets: trends in higher education in Western Europe, 1988-1990. European Journal of Education, 25(2), 195-222.

Osmanov, A. M., Yesetova, A. M. (2012). Modern peculiarities and conditions for the development of the educational services market in Russia. Problems of Science and Education, 3, 354-357.

Petrenko, L. M. (2010). Competitiveness of the vocational education institution and ways to achieve it. Continuing vocational education in the context of European integration: theory, experience, forecast: scient. papers collection (part 1), 134-140.

Podzigun, S. M. (2014). Theoretical aspects of the educational services market development in Ukraine in the context of foreign experience. Scientific Bulletin of the Kherson State University. Economics, $7(2), 57-60$.

Poyta, I. O. (2011). The peculiarities of the educational services market formation. National economy of Ukraine: theory and practice of management. State Institution "Institute of Economics of Natural Resources and Sustainable Development of the National Academy of Sciences of Ukraine, 249-253.

Prokopenko, L. L. (2013). State policy on the development of the non-governmental sector of higher education in Ukraine at the beginning of the $20^{\text {th }}$ century. Aspects of public administration, 2, 5-10.

Rubin, Yu. B. (2011). Education market: from the quality to the competitive business models (Part 2). Higher education in Russia, 4, 33-46. 
Shender, A. R. (2013). Estimation of regional markets for educational services in the field of higher education in conditions of active influence of the environment. Regional economics, 3, 199-210.

Tikhonov, A. N. (1998). Management of modern education. Social and economic aspects. Moscow: Vita-Press Publishing House.

Voyna, G. G. (2013). The Approach and Mechanisms of State Regulation of the Development of the Market for Higher Education Services in Ukraine. Scientific Investigations on the State and Municipal Management, 2, 142-158.

Yaschuk, T. A. (2013). Educational Services Market: Essence and Development Trends. Innovative Economics, 8, 246-249.

Yeliseyeva, O. K. Tarasenko, T. V. (2012). Assessment of the Quality of the Educational Services Market Development in Ukraine. Business Inform, 5, 241-245.

Yevmenkova, K. M. (2011). The principal ways of improving the educational services market in Ukraine. Cherkasy University Bulletin: Economics, 207, 23-27.

Yurchuk, L. M. The mechanism of state regulation of the process of activating public activity of educators in Vinnytschyna. Public Administration: Theory and Practice, 1. Retrieved June 62018 from: http://nbuv.gov.ua/ UJRN/Patp_2013_1_6

Zerkal, M. M., Siryi, Y. (2016). Periodization of the history of higher education in Ukraine and the practice of subsidiaries activities in the period of Ukraine's independence. Scientific works of the Petro Mohyla Chornomorsky State University of the Kyiv-Mohyla Academy complex. Series: History, 274(262), 7-11. 